\title{
6-n-propyltiouracil (PROP) taster status in Brazilian adults
}

\author{
Sensibilidade ao 6-n-propiltiouracil (PROP) em adultos brasileiros
}

\author{
Maria Carolina Batista Campos VON ATZINGEN ${ }^{1 *}$, Maria Elisabeth Machado Pinto e SILVA ${ }^{1}$
}

\begin{abstract}
The objective of this study was to determine PROP (6-n-propyltiouracil) taster status in adults and its relationship with anthropometric variables and pleasantness of sugar, salt, and fat. A total of 123 subjects rated the intensity of PROP and sodium cloride ( $\mathrm{NaCl}$ ) solutions using the labeled magnitude scale. For pleasantness evaluation, it was used concentrated orange juice (sugar) and mashed potato (salt and fat). The subjects were classified as non-tasters $(n=35)$, medium-tasters $(n=33)$ and super-tasters $(n=55)$. In this study, no relationship was found between PROP taster status and age, sex, weight, body mass index, and pleasantness. Although genetic markers may influence the degree of liking of certain foods, one must consider that the mechanisms influencing eating behavior in humans are complex, and that psychological, social, and economic factors play a key role in response to food.

Keywords: propylthiouracil; body mass index; pleasantness.
\end{abstract}

\section{Resumo}

O objetivo deste trabalho foi determinar o nível de sensibilidade ao PROP (6-n-propiltiouracil) em adultos e sua relação com as variáveis antropométricas e o grau de gostar de açúcar, sal e gordura. Um grupo de 123 indivíduos avaliou a intensidade de soluções de PROP e cloreto de sódio $(\mathrm{NaCl})$ por meio da escala de magnitude rotulada. Para a avaliação do grau de gostar, foram utilizados suco de laranja (açúcar) e purê de batata (sal e gordura). Os indivíduos foram classificados em não sensíveis $(n=35)$, médio sensíveis $(n=33)$ e supersensíveis $(n=55)$. Não foi encontrada relação entre nível de sensibilidade ao PROP e idade, gênero, peso e índice de massa corporal, e grau de gostar. Embora marcadores genéticos possam influenciar o grau de gostar de determinados alimentos, os mecanismos que influenciam o comportamento alimentar são complexos, sendo que os aspectos psicológicos, sociais e econômicos desempenham um importante papel na resposta atribuída aos alimentos.

Palavras-chave: propiltiouracil; índice de massa corporal; grau de gostar.

\section{Introduction}

Taste sensitivity to the bitter compound 6-n-propylthiouracil (PROP) is a genetic trait present in $70 \%$ of the population, and it is sensitive even at low concentrations of the compound (FOX, 1932). PROP tasters have a higher density of fungiform papillae and tend to perceive a wide variety of compounds, such as caffeine, sucrose, pepper, and fat with greater intensity (TEPPER, 2008; TEPPER; CHRISTENSEN; CAO, 2001).

This phenotype is a marker of individual differences in taste perception, which in turn influences food preferences and consumption (TEPPER, 2008). Due to their increased sensitivity, taster individuals tend to avoid sweet and fatty foods, and therefore they generally have lower weight and lower values of body mass index (BMI) than non-tasters (BARTOSHUK, 2000; GOLDSTEIN; DAUN; TEPPER, 2005). This sensitivity can govern the hedonic response to sweets. Looy and Weingarten (1992) noted that non-tasters are classified as sweet likers, while tasters tend to dislike sweets. A total of $67 \%$ of the super-tasters studied by Yeomans et al. (2007) disliked sweets compared with $12 \%$ of non-tasters.
It has been speculated that non-tasters have a higher degree of liking and consumption of fatty foods, which can contribute to weight gain and incidence of obesity-related diseases (DUFFY, 2007; TEPPER; ULLRICH, 2002).

In addition to sweets and fat, sensitivity to PROP has been associated with increased sensitivity and aversion to bitter compounds and bitter foods (GLANVILLE; KAPLAN, 1963; DREWNOWSKI; ROCK, 1995), which may be related to the low consumption of cruciferous vegetables (TEPPER, 2008), such as broccoli, cabbage, cauliflower, brussels sprouts, and radish (FAHEY; ZALCMANN; TALALAY, 2001). Given the fact that this differential sensitivity may influence food choice, correct identification of this group is important in the association of this phenotype with feeding behavior (TEPPER, 2008). Nevertheless, there is no available information about PROP taster status of the Brazilian adult population.

The objective of the present study was to determine PROP taster status in a sample of Brazilian subjects and its relationship with anthropometric variables and pleasantness.

\footnotetext{
Received 5/7/2011

Accepted 29/2/2012 (005368)

${ }_{1}^{1}$ Departamento de Nutrição, Faculdade de Saúde Pública, Universidade de São Paulo - USP, Av. Dr. Arnaldo, 715, CEP 01246 904, São Paulo, SP, Brasil,

e-mail:movon@uol.com.br

${ }^{*}$ Corresponding author
}

DOI: http://dx.doi.org/10.1590/S0101-20612012005000108 


\section{Materials and methods}

\subsection{Subjects}

Volunteers from the Public Health College - USP (University of São Paulo) and Health Center Geraldo Horacio de Paula Souza, located in São Paulo, Brazil were recruited via Internet. Individuals younger than 20 years or over 60 years, pregnant women, those with food allergies or colds, and those using medicines that alter sensory perception were excluded.

The subjects were asked to state their age and gender.

BMI was calculated by dividing weight in kilograms by height in meters squared using reference values of the WHO (WORLD..., 2000) for classification. To measure weight, a Tanita digital balance with a capacity of $200 \mathrm{~kg}$, accurate to $200 \mathrm{~g}$, was used. The subjects were weighed in light clothing without shoes. To measure height, individuals stood erect with their arms alongside the body and heels, calves, hips, shoulders, and head against the wall with head positioned according to Frankfort's plan: eyes fixed on the horizontal plane parallel to the ground. The measurement was performed in duplicate, and the difference between values did not exceed $1.5 \mathrm{~mm}$ (GORDON; CHUMLEA; ROCHE, 1988). A stadiometer accurate to $0.1 \mathrm{~cm}$ was used.

\subsection{Taste stimuli}

The method used for determining PROP taster status involved the use of one PROP concentration $\left(0.32 \mathrm{mmol}^{-1} \mathrm{~L}^{-1}\right)$ and one $\mathrm{NaCl}$ (sodium chloride) concentration $\left(0.1 \mathrm{~mol} \cdot \mathrm{L}^{-1}\right)$. The PROP and $\mathrm{NaCl}$ solutions were prepared by dissolving PROP and $\mathrm{NaCl}$ in deionized water under heat and agitation, and then stored at $5{ }^{\circ} \mathrm{C}$. Before testing, the solutions were brought to room temperature (TEPPER; CHRISTENSEN; CAO, 2001). Samples of $10 \mathrm{~mL}$ of PROP and $\mathrm{NaCl}$ were presented twice in white odorless plastic cups coded with randomly chosen threedigit numbers.

\subsection{Rating scale}

The subjects rated the intensity of each stimulus using the Labeled Magnitude Scale (LMS). The LMS is a semi-logarithmic scale of $100 \mathrm{~mm}$ which includes descriptors ranging from "weakly detectable" to "strongest imaginable", which rate the taste sensation created by the solutions presented. The participants were instructed to taste the solutions and rate them on the scale by comparing with the oral sensations of everyday life (food and beverages, hot, cold, spicy, toothpaste, medicines, etc.) (GREEN et al., 1996).

Numerical scores were employed to classify individuals in relation to PROP taster status with the label descriptors of the LMS. Those who assigned a value of less than or equal to moderate were initially classified as non-tasters, whereas those who assigned values of greater than or equal to very strong were deemed super-tasters, while medium-tasters fell between these two limits. The cut-off points were confirmed with a confidence interval around the mean for each PROP taster status (TEPPER; CHRISTENSEN; CAO, 2001).

\subsection{Pleasantness}

The subjects received concentrated orange juice diluted according to the manufacturer's guidance by adding $100 \mathrm{~mL}$ juice to $300 \mathrm{~mL}$ water. Five concentration levels of sucrose (1, $3,5,7$, and $9 \% \mathrm{w} / \mathrm{w}$ ) were prepared based on results of extensive pretests. The subjects received $20 \mathrm{~mL}$ of each concentration (MEILGAARD; CIVILLE; CARR, 1999) at $8{ }^{\circ} \mathrm{C}$.

To determine the pleasantness of salt and fat, mashed potato was prepared according to the manufacturer's directions by adding $50 \mathrm{~g}$ of instant dry potato to $250 \mathrm{~mL}$ boiling water and $200 \mathrm{~mL}$ skim milk. Five concentration levels of salt $(0,0.5$, $1.0,1.5$, and $2.0 \% \mathrm{w} / \mathrm{w}$ ) and five concentrations of margarine $(0,1.3,2.6,3.9$, and $5.2 \% \mathrm{w} / \mathrm{w})$ were prepared, also based on results of pretests. The samples were prepared on the same day of the test. The mashed potato was offered in quantities of $30 \mathrm{~g}$ at a temperature of $45^{\circ} \mathrm{C}$ (MELA; SACCHETTI, 1991; MEILGAARD; CIVILLE; CARR, 1999). The order of presentation of the different concentrations was random ensuring that neither of the extremes was presented first (JONG; GRAAF; VAN STAVEREN, 1996). All samples were offered in white odorless plastic cups, coded with randomly chosen three-digit numbers. The subjects rinsed out their mouth with tap water between stimuli. The tests were performed under white light.

Orange juice and mashed potato were chosen because these types of food are familiar to the population, and both are convenient vehicles to manipulate the intensity of several attributes.

The individuals were instructed to rate pleasantness on a seven-point category scale $(1=$ dislike extremely, $4=$ neither like nor dislike, 7 = like extremely) (MEILGAARD; CIVILLE; CARR, 1999).

Sensory analysis was carried out in the morning with an interval of at least 2 hours between the last meal and the test (MEILGAARD; CIVILLE; CARR, 1999).

The tests were performed at the Laboratory of Sensory Analysis of the Public Health College - USP.

\subsection{Statistical analysis}

The Statistical Package for the Social Sciences (version 17.0 for Windows, 2008, SPSS Inc, Chicago, IL) was used for all data analyses.

The results were presented as frequency, mean, standard deviation, and minimum and maximum values.

Comparisons of the means of anthropometric variables and gender among the three taster groups were performed using the Kruskal-Wallis test. The Student-Newman-Keuls test was used to determine group differences in mean ratings.

Nonparametric analyses of repeated ordinal categorical data were performed to verify the relationship between PROP taster status and pleasantness (SINGER; POLETO; ROSA, 2004). A value of $\mathrm{p}<0.05$ was used as criterion for statistical significance. 
The study was approved by the Research Ethics Committee of the Public Health College, USP (number 224/07). All subjects gave written informed consent.

\section{Results and discussion}

\subsection{Subject characteristics}

A total of 123 individuals, majority of women (76\%), aged between 20 and 30 years participated in the study (Table 1).

\subsection{PROP taster status}

A total of $72 \%$ of individuals had some degree of sensitivity, with the majority being super-tasters (45\%) and $28 \%$ nontasters, as shown in Table 2.

Figure 1 shows the classification of individuals by level of sensitivity to PROP. The upper limit of the confidence interval for non-tasters was $8.2 \mathrm{~mm}$, approximately "weak" on the scale; the lower limit for the super-tasters was $70.9 \mathrm{~mm}$, corresponding to "very strong", while medium-tasters fell between these values. Significant differences were found among the three groups $(\mathrm{p}<0.01)$.

The LMS scale used in this study has a finite upper limit and provides individuals, especially super-tasters, with greater freedom of expression. Labeled scales allow better discrimination of levels of sensitivity (ESSICK et al., 2003; KIRKMEYER; TEPPER, 2003; PRESCOTT; BARTOSHUK; PRUTKIN, 2004).

The cutoff points found for classifying PROP taster status in our sample were similar to those described in the literature. Goldstein, Daun and Tepper (2005) found values of $77 \mathrm{~mm}$ for super-tasters and $9 \mathrm{~mm}$ for non-tasters. The distribution of phenotypes found in the present study was also consistent with that reported in the literature showing that although the frequency of non-tasters varies according to race and ethnicity, approximately $30 \%$ of the Caucasian population have this characteristic (FOX, 1932; TEPPER, 2008).

\subsection{Anthropometric data}

Age, weight, and BMI were similar across all groups. There were no statistically significant differences between age, weight, and body mass index in relation to PROP taster status or gender $(\mathrm{p}=0.06)$, as can be seen in Table 3 .

Table 1. Distribution of demographic characteristics of adults studied.

\begin{tabular}{lll}
\hline \multicolumn{1}{c}{ Characteristic } & $\mathrm{N}$ & $\%$ \\
\hline Gender & & \\
$\quad$ Female & 93 & 76 \\
$\quad$ Male & 30 & 24 \\
Age & & \\
$20-30$ & 62 & 50 \\
$31-40$ & 29 & 24 \\
$41-50$ & 18 & 15 \\
$51-60$ & 14 & 11 \\
\hline
\end{tabular}

Table 2. Distribution of study population by PROP taster status.

\begin{tabular}{lll}
\hline \multicolumn{1}{c}{ Taster status } & N & $\%$ \\
\hline Nontaster & 35 & 28 \\
Medium taster & 33 & 27 \\
Super taster & 55 & 45 \\
\hline
\end{tabular}

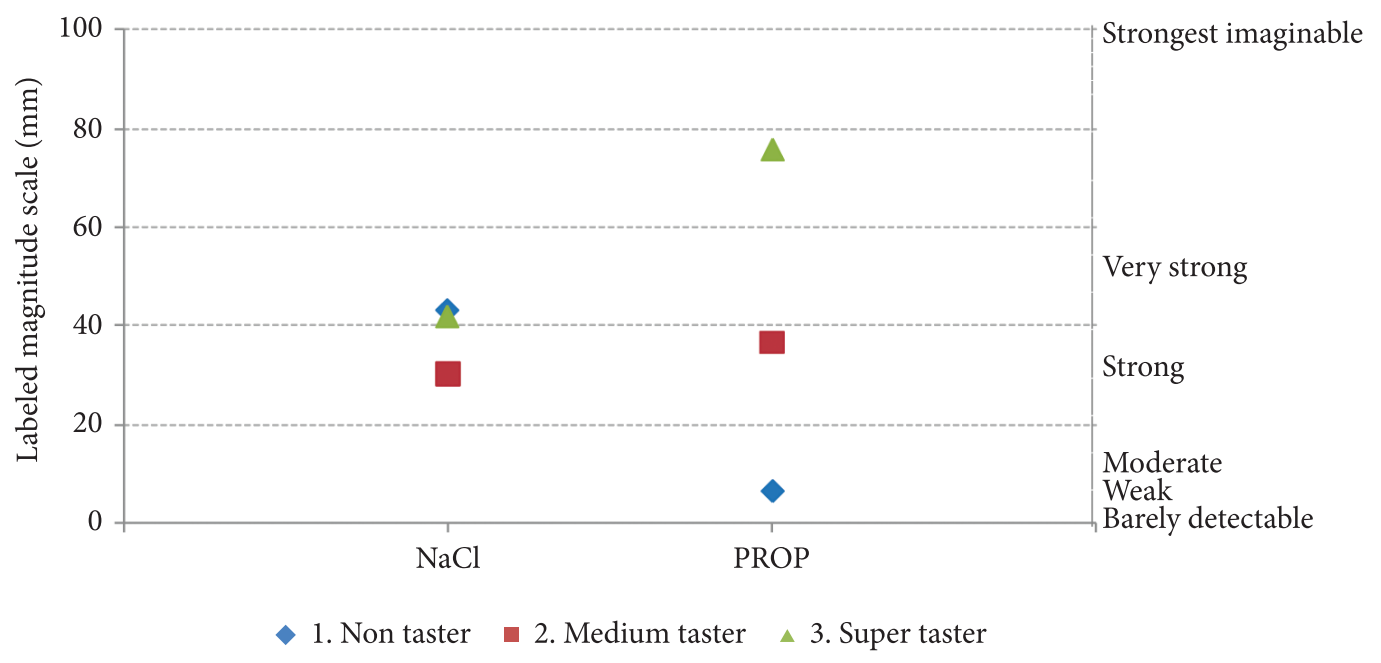

Figure 1. Classification of subjects by PROP taster status (means). 
Studies associating sensitivity to PROP with anthropometric characteristics remain controversial. Drewnowski, Henderson and Cockroft (2007), in studies investigating sensitivity to PROP in a population of women, verified no statistically significant difference in sensitivity for age, weight, or body mass index. Bajec and Pickering (2010) also found no association between PROP taster status and BMI in the adult population studied.

Although it is acknowledged, for unknown reasons, that super-tasting is more common among women (TEPPER, 2008), the present study showed no association between sensitivity to PROP and gender.

Drewnowski, Henderson and Cockroft (2001) found no association between body weight and taste responsiveness to PROP in the population of men and women studied. Goldstein, Daun and Tepper (2005) however, observed that BMI in nontaster women was 6.2 units higher than that in the super-tasters. Tepper and Nurse (1998) observed an inverse association between taste sensitivity to PROP and BMI in male college students, a pattern also verified in young women (KAMINSKI; HENDERSON; DREWNOWSKI, 2000) and young adults of both sexes (YACKINOUS; GUINARD, 2002).

Caratin (2004) evaluated children aged 7-10 years and found no association between sensitivity to PROP and nutritional status although most of the obese children were classified as non-tasters.

\subsection{Pleasantness}

There was no significant interaction effect between PROP taster status and concentration of sucrose $(p=0.12)$, salt $(\mathrm{p}=0.42)$, and fat $(\mathrm{p}=0.80)$; however, non-tasters preferred the $5 \%$ sugar orange juice assigning a mean pleasantness of 4.3 , whereas medium- and super-tasters scored the $7 \%$ concentration with the highest values of 4.8 and 4.5 , respectively, as shown in Figure 2.

In this study, no association was observed between sensitivity to PROP and degree of liking for sucrose, salt, and fat in the preparations evaluated. The results of the pleasantness of orange juice were in line with those of several studies finding no significant associations between acceptance of sweetened beverages in adults and PROP responsiveness (TEPPER, 2008). Taster children however, showed a greater preference for sugary drinks and candy than non-taster children (KELLER; TEPPER, 2004), a finding also observed by Mennella, Pepino and Reed (2005), who noted a preference for solutions with higher concentrations of sucrose and also for cereals with higher sugar content by taster children. Studies suggest that the influence of
PROP on preference for sweets diminishes with increasing age (TEPPER, 2008). According to Feeney (2011), both age and gender modify the relation between PROP taster status and food preference and intakes.

Although lowest hedonic values were assigned by the three groups for the $9 \%$ sucrose concentration, there was greater rejection by non-tasters, as depicted in Figure 2.

Regarding salt, non-tasters attributed the highest score (4.6) to the $1 \%$ concentration. Medium- and super-tasters preferred the $0.5 \%$ sample with a mean pleasantness of 4.8 and 5.2, respectively (Figure 3 ). For the 1\% concentration, lowest scores were given regardless of taster status.

Few studies have examined the relationship between sensitivity to PROP and pleasantness of salt and fat. The present study found no relationship between sensitivity to PROP and degree of liking of salt in mashed potatoes, in contrast to Pasquet et al. (2002), who demonstrated that sensitivity to PROP was negatively associated with hedonic values for salt solutions.

Hayes, Sullivan and Duffy (2010) verified that PROP supertasters consumed more sodium through food, as salt was more important to preference, both for its salty taste and masking of bitterness.

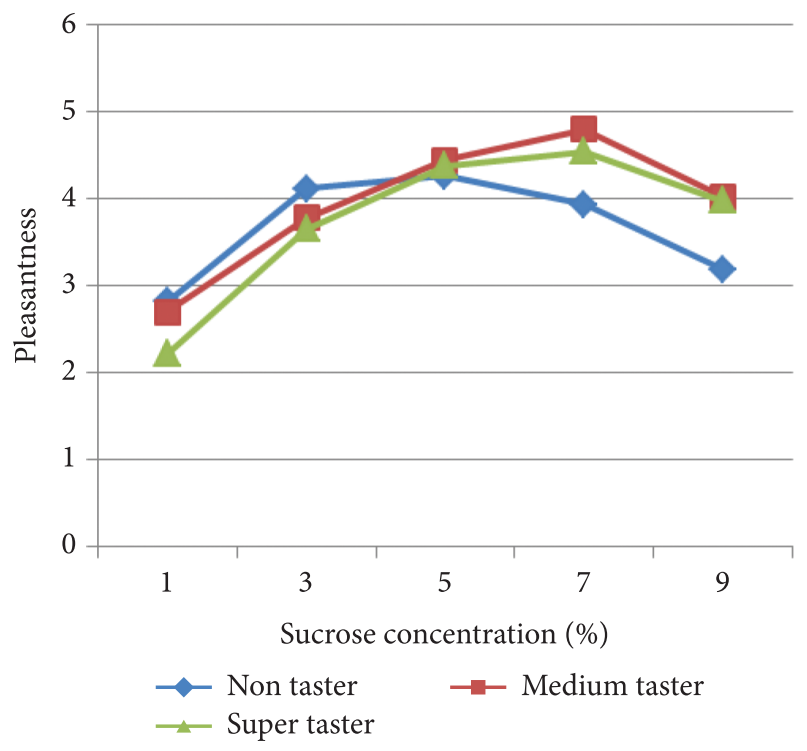

Figure 2. Mean rated pleasantness on a seven-point category scale as a function of sucrose concentration in orange juice by taster status.

Table 3. Anthropometric data by PROP taster status (non tasters, medium tasters and super tasters).

\begin{tabular}{|c|c|c|c|c|c|c|c|}
\hline \multirow{2}{*}{$\begin{array}{c}\text { Anthropometric } \\
\text { data }\end{array}$} & \multicolumn{2}{|c|}{ Nontasters $(\mathrm{n}=35)$} & \multicolumn{2}{|c|}{ Medium tasters $(\mathrm{n}=33)$} & \multicolumn{2}{|c|}{ Supertasters $(\mathrm{n}=55)$} & \multirow[t]{2}{*}{ p-value } \\
\hline & Mean \pm S.D. & Min-Max & Mean \pm S.D. & Min-Max & Mean \pm S.D. & Min-Max & \\
\hline Age $(y)$ & $35.0 \pm 11.0$ & $22.0-58.0$ & $34.0 \pm 11.0$ & $20.0-53.0$ & $33.0 \pm 10.0$ & $20.0-57.0$ & 0.77 \\
\hline Weight (kg) & $69.4 \pm 16.0$ & $41.0-108.0$ & $72.2 \pm 19.5$ & $46.4-117.0$ & $73.7 \pm 20.5$ & $46.0-142.0$ & 0.82 \\
\hline Body mass index & $26.2 \pm 8.4$ & $18.7-49.7$ & $26.8 \pm 5.7$ & $19.5-43.7$ & $26.3 \pm 6.3$ & $18.7-43.6$ & 0.31 \\
\hline
\end{tabular}

$\mathrm{p}<0.05$; S.D. $=$ standard deviation; Min = Minimum; $\mathrm{Max}=$ Maximum. 
With regard to fat, mean pleasantness responses for the non-tasters were highest for the $1.3 \%$ mashed potato (4.5), whereas medium- and super-tasters assigned the highest values to the $2.6 \%$ concentration ( 4.7 and 5.2, respectively), as shown in Figure 4.

The most preferred samples were less clear considering the similarity of the three groups at all concentrations of $1.3 \%$ and above.

This study found no significant interaction effect between PROP taster status and concentration of fat in mashed potato. By contrast, Tepper and Nurse (1998) observed a preference for

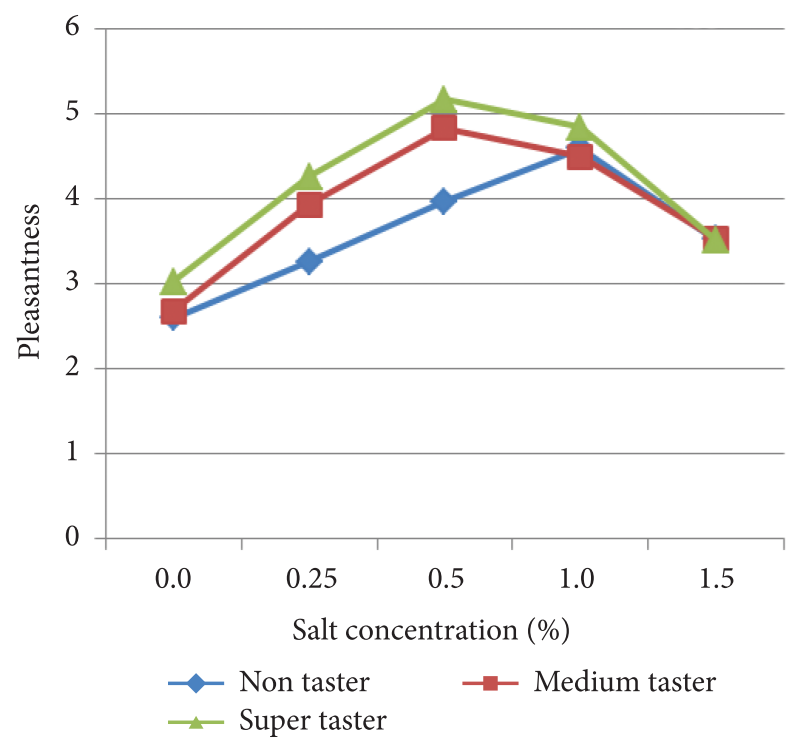

Figure 3. Mean rated pleasantness on a seven-point category scale as a function of salt concentration in mashed potato by taster status.

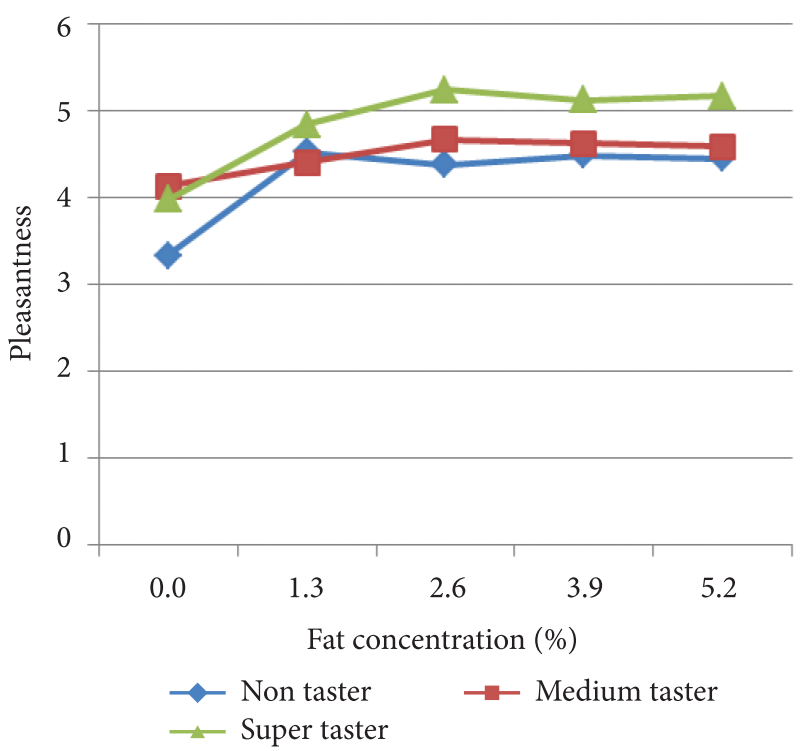

Figure 4. Mean rated pleasantness on a seven-point category scale as a function of fat concentration in mashed potato by taster status. salad dressings with high fat content in a sample of non-taster university students. Another study evaluating mashed potatoes, chocolate, and potato chips found no differences between taster groups for fat consumption (YACKINOUS; GUINARD, 2001). The reasons for the discrepancies in these results are unclear, but differences in methodology may be one explanation (TEPPER, 2008). Preschool female non-tasters studied by Keller et al. (2002) assigned higher scores for the pleasantness of whole milk than those assigned by tasters, a finding not observed for boys. The same study observed a higher frequency of consumption of fats in vegetable oils and salad dressings for the non-taster girls.

\section{Conclusions}

PROP taster status was identified in the sample of Brazilian subjects evaluated. This study found no relationship between the level of sensitivity to PROP and age, sex, weight, BMI, and pleasantness.

Although the genetic markers may influence the degree of liking and consumption of certain foods, one must consider that the mechanisms influencing eating behavior in humans are complex and that psychological, social, and economic factors also play a key role in response to food. However, it is imperative that sensory response to foods be taken into account in nutrition education and intervention strategies.

It is important to consider that there are no studies for the Brazilian adult population regarding PROP taster status, which reinforces the need for further research in this area which may be of use to public health workers improving the understanding behind the factors that drive food choices.

\section{Acknowledgements}

The authors are grateful for the financial support provided by the São Paulo State Research Foundation (FAPESP).

\section{References}

BAJEC, M. R.; PICKERING, G. J. Association of thermal taste and PROP responsiveness with food liking, neophobia, body mass index, and waist circumference. Food Quality and Preference, v. 21, n. 6, p. 589-601, 2010. http://dx.doi.org/10.1016/j.foodqual.2010.03.007

BARTOSHUK, L. M. Comparing sensory experiences across individuals: Recent psychophysical advances illuminate genetic variation in taste perception. Chemical Senses, v. 25, n. 4, p. 447-460, 2000. PMid:10944509. http://dx.doi.org/10.1093/ chemse/25.4.447

CARATIN, C. V. S. Análise dos limiares de detecção dos gostos básicos e sensibilidade ao 6-n-propiltiouracil em crianças de 7 a 10 anos. 2004. 109 f. Dissertação (Mestrado em Saúde Pública)Faculdade de Saúde Pública, Universidade de São Paulo, 2004.

DREWNOWSKI, A.; HENDERSON, S. A.; COCKROFT, J. E. Genetic sensitivity to 6-n-propylthiouracil has no influence on dietary patterns, body mass indexes, or plasma lipid profiles of women. Journal of the American Dietetic Association, v. 107, n. 8, p. 1340-1348, 2007. PMid:17659901. http://dx.doi.org/10.1016/j. jada.2007.05.013 
DREWNOWSKI, A.; ROCK, C. L. The influence of genetic taste markers on food acceptance. American Journal of Clinical Nutrition, v. 62, n. 3, p. 506-511, 1995. PMid:7661111.

DUFFY, V. B. Variation in oral sensation: Implications for diet and health. Current Opinion in Gastroenterology, v. 23, n. 2, p. 171, 2007. PMid:17268246. http://dx.doi.org/10.1097/ MOG.0b013e3280147d50

ESSICK, G. K. et al. Lingual tactile acuity, taste perception, and the density and diameter of fungiform papillae in female subjects. Physiology Behavior, v. 80, n. 2-3, p. 289-302, 2003. http://dx.doi. org/10.1016/j.physbeh.2003.08.007

FAHEY, J. D.; ZALCMANN, A. T.; TALALAY, P. The chemical diversity and distribution of glucosinolates and isothiocyanates among plants. Phytochemical, v. 56, n. 1, p. 5-51, 2001. http://dx.doi.org/10.1016/ S0031-9422(00)00316-2

FEENEY, E. The impact of bitter perception and genotypic variation of TAS2R38 on food choice. Nutrition Bulletin, v. 36, n. 1, p. 20-33, 2011. http://dx.doi.org/10.1111/j.1467-3010.2010.01870.x

FOX, A. L. The relationship between chemical constitution and taste. Proceedings of the National Academy of Sciences, v. 18, n. 1, p. 115-120, 1932. http://dx.doi.org/10.1073/pnas.18.1.115

GLANVILLE, E. V.; KAPLAN, A. R. Food preference and sensitivity of taste for bitter compounds. Nature, v. 205, n. 4974, p. 851-853, 1965. http://dx.doi.org/10.1038/205851a0

GOldsteIN, G. L.; DAUN, H.; TEPPER, B. J. Adiposity in middle-aged women is associated with genetic taste blindness to 6-n-propylthiouracil. Obesity Research, v. 13, n. 6, p. 1017-1023, 2005. PMid:15976144. http://dx.doi.org/10.1038/ oby.2005.119

GORdON, C. C.; CHUMLEA, W. C.; ROCHE, A. F. Stature, recumbent length and weight. In: LOHMAN, T. G.; ROCHE, A. F.; MARTORELL, L. Anthropometric standardization reference manual. Champaign: Human Kinetics Books, 1988. p. 3-8.

GREEN, B. G. et al. Evaluating the labeled magnitude scale for measuring sensations of taste and smell. Chemical Senses, v. 21, n. 3, p. 323-334, 1996. PMid:8670711. http://dx.doi.org/10.1093/ chemse/21.3.323

HAYES, J. E.; SULLIVAN, B. S.; DUFFY, V. B. Explaining variability in sodium intake through oral sensory phenotype, salt sensation and liking. Physiology Behavior, v. 100, n. 4, p. 369-380, 2010. http:// dx.doi.org/10.1016/j.physbeh.2010.03.017

JONG, N.; GRAAF, C.; VAN STAVEREN, W. A. Effect of sucrose in breakfast items on pleasantness and food intake in the elderly. Physiology Behavior, v. 60, n. 6, p. 1453-1462, 1996. http://dx.doi. org/10.1016/S0031-9384(96)00306-X

KAMINSKI, L. C.; HENDERSON, S. A.; DREWNOWSKI, A. Young women's food preferences and taste responsiveness to 6-n-propylthiouracil (PROP). Physiology Behavior, v. 68, n. 5, p. 691-697, 2000. http://dx.doi.org/10.1016/S0031-9384(99)00240-1

KELLER, K. L. et al. Genetic taste sensitivity to 6-n-propylthiouracil influences food preference and reported intake in preschool children. Appetite, v. 38, n. 1, p. 3-12, 2002. PMid:11883912. http:// dx.doi.org/10.1006/appe.2001.0441

KELLER, K. L.; TEPPER, B. J. Inherited taste sensitivity to 6-n-propylthiouracil in diet and body weight in children. Obesity Research, v. 12, n. 6, p. 904-912, 2004. PMid:15229328. http://dx.doi. org/10.1038/oby.2004.110

KIRKMEYER, S. V.; TEPPER, B. J. Understanding creaminess perception of dairy products using free-choice profiling and genetic responsivity to 6-n-propylthiouracil. Chemical Senses, v. 28, n. 6, p. 527-536, 2003. PMid:12907590. http://dx.doi.org/10.1093/ chemse/28.6.527

LOOY, H.; WEINGARTEN, H. P. Facial expressions and genetic sensitivity to 6-n-propylthiouracil predict hedonic response to sweet. Physiology Behavior, v. 52, n. 1, p. 75-82, 1992. http://dx.doi. org/10.1016/0031-9384(92)90435-5

MEILGAARD, M.; CIVILLE, G. V.; CARR, T. B. Sensory evaluation techniques. Boca Raton: CRC Press, 1999. 387 p. http://dx.doi. org/10.1201/9781439832271

MELA, D. J.; SACCHETTI, D. A. Sensory preferences for fats: relationships with diet and body composition. American Journal of Clinical Nutrition, v. 53, n. 4, p. 908-915, 1991. PMid:2008871.

MENNELLA, J. A.; PEPINO, M. Y.; REED, D. R. Genetic and environmental determinants of bitter perception and sweet preferences. Pediatrics, v. 115, n. 2, p. 216-222, 2005. PMid:15687429 PMCid:1397914. http://dx.doi.org/10.1542/peds.2004-1582

PASQUET, P. et al. Relationships between threshold-based PROP sensitivity and food preferences of Tunisians. Appetite, v. 39, n. 2, p. 167-173, 2002. PMid:12354685. http://dx.doi.org/10.1006/ appe. 2002.0503

PRESCOTT, J.; BARTOSHUK, L. M.; PRUTKIN, J. 6-n-Propylthiouracil tasting and the perception of nontaste oral sensations. In: PRESCOTT, J.; TEPPER, B. J. (Eds.). Genetic variation in taste sensitivity. New York: Marcel Dekker, 2004. p. 89-104. http://dx.doi. org/10.1201/9780203023433.ch4

SINGER, J. M.; POLETO, F. Z.; ROSA, P. Parametric and nonparametric analysis of repeated ordinal categorical data. Biometrical Journal, v. 46, n. 4, p. 460-473, 2004. http://dx.doi.org/10.1002/ bimj. 200310045

TEPPER, B. J. Nutritional implications of genetic taste variation: the role of PROP sensitivity and other taste phenotypes. Annual Review of Nutrition, v. 28, p. 367-388, 2008. PMid:18407743. http://dx.doi. org/10.1146/annurev.nutr.28.061807.155458

TEPPER, B. J.; CHRISTENSEN, C. M.; CAO, J. Development of brief methods to classify individuals by PROP taster status. Physiology Behavior, v. 73, n. 4, p. 571-577, 2001. http://dx.doi.org/10.1016/ S0031-9384(01)00500-5

TEPPER, B. J.; NURSE, R. J. PROP taster status is related to the perception and preference for fat. Annual New York Academy Science, v. 855, n. 6, p. 802-804, 1998. PMid:9929688. http://dx.doi. org/10.1111/j.1749-6632.1998.tb10662.x

TEPPER, B. J.; ULLRICH, N. V. Influence of genetic taste sensitivity to 6-npropylthiouracil (PROP), dietary restraint and disinhibition on body mass index. Physiology Behavior, v. 75, n. 3, p. 305-312, 2002. http://dx.doi.org/10.1016/S0031-9384(01)00664-3

WORLD HEALTH ORGANIZATION - WHO. Obesity: preventing and managing the global epidemic. Report of a WHO Consultation. Geneva: WHO, 2000. (WHO Technical Report Series, n. 894).

YACKINOUS, C. A.; GUINARD, J. X. Relation between PROP taster status and fat perception, touch, and olfaction. Physiology Behavior, v. 72, n. 3, p. 427-437, 2001. http://dx.doi.org/10.1016/ S0031-9384(00)00430-3

YACKINOUS, C. A.; GUINARD, J. X. Relation between PROP (6-n-propylthiouracil) taster status, taste anatomy and dietary intake measures for young men and women. Appetite, v. 38, n. 3, p. 201-209, 2002. PMid:12071686. http://dx.doi.org/10.1006/ appe.2001.0481

YEOMANS, M. et al. Human hedonic responses to sweetness: role of taste genetics and anatomy. Physiology Behavior, v. 91, n. 2-3, p. 264-273, 2007. http://dx.doi.org/10.1016/j.physbeh.2007.03.011 